\title{
ANALISIS PENGARUH PERTUMBUHAN EKONOMI, PENDAPATAN PERKAPITA, INFLASI DAN PENGANGGURAN TERHADAP JUMLAH PENDUDUK MISKIN DI PROVINSI SUMATERA UTARA
}

\section{Oleh \\ A. Mahendra}

\begin{abstract}
Abstrak
Kemiskinan dipandang sebagai kondisi di mana seseorang atau sekelompok orang, laki-laki atau perempuan, tidak terpenuhi hak-hak dasar mereka memenuhi syarat untuk kehidupan yang bermartabat.Sudut pandang kemiskinan adalah pendekatan berbasis hak yang mengakui bahwa masyarakat miskin memiliki hak dasar yang sama dengan anggota masyarakat lainnya. Penelitian ini bertujuan untuk mengetahui Faktor Yang Mempengaruhi Jumlah Penduduk Miskin Sumatera Utara 20032014. Variabel yang digunakan meliputi Pertumbuhan Ekonomi, Pendapatan Per Kapita, Inflasi dan Pengangguran. Metode yang digunakan adalah metode Ordinary Least Square (OLS), yang menggunakan beberapa metode regresi linear untuk mengelola data menggunakan SPSS 22.Hasil penelitian ini menunjukkan bahwa koefisien determinasi $\left(\mathrm{R}^{2}\right)$ dari 0,698 , yang berarti bahwa variabel independen, yaitu pertumbuhan ekonomi, pendapatan per kapita, inflasi, dan pengangguran mempengaruhi jumlah penduduk miskin di Provinsi Sumatera Utara.
\end{abstract}

Kata kunci: Kemiskinan, Pertumbuhan Ekonomi, Pendapatan Per Kapita, Inflasi dan Pengangguran

\section{PENDAHULUAN}

Salah satu tujuan pembangunan nasional adalah meningkatkan kinerja perekonomian agar mampu menciptakan lapangan kerja dan menata kehidupan yang layak bagi seluruh rakyat yang pada gilirannya akan mewujudkan kesejahteraan penduduk Indonesia. Salah satu sasaran pembangunan nasional adalah menurunkan tingkat kemiskinan. Kemiskinan merupakan salah satu penyakit dalam ekonomi, sehingga harus disembuhkan atau paling tidak dikurangi.Permasalahan kemiskinan memang merupakan permasalahan yang kompleks dan bersifat multidimensional.Oleh karena itu, upaya pengentasan kemiskinan harus 
dilakukan secara komprehensif, mencakup berbagai aspek kehidupan masyarakat, dan dilaksanakan secara terpadu (M. Nasir, dkk 2008).

Data kemiskinan yang baik dapat digunakan untuk mengevaluasi kebijakan pemerintah terhadap kemiskinan, membandingkan kemiskinan antar waktu dan daerah, serta menentukan target penduduk miskin dengan tujuan untuk memperbaiki kualitas hidup mereka.Secara umum kemiskinan didefinisikan sebagai kondisi dimana seseorang atau sekelompok orang tidak mampu memenuhi hak-hak dasarnya untuk mempertahankan dan mengembangkan kehidupan yang bermartabat.Definisi yang sangat luas ini menunjukkan bahwa kemiskinan merupakan masalah multi dimensional, sehingga tidak mudah untuk mengukur kemiskinan dan perlu kesepakatan pendekatan pengukuran yang dipakai.(BPS \& World Bank).

Kemiskinan merupakan masalah sosial yang senantiasa hadir di tengah-tengah masyarakat, khususnya di negara-negara berkembang.Dalam konteks masyarakat Indonesia, masalah kemiskinan juga merupakan masalah sosial yang senantiasa relevan untuk dikaji secara terus menerus. Bukan saja karena masalah kemiskinan telah ada sejak lama, melainkan pula karena hingga kini belum bisa diselesaikan dan bahkan kini gejalanya semakin meningkat sejalan dengan krisis multidimensional yang masih dihadapi oleh bangsa Indonesia.(Alfian; 2000).

Kemiskinan tidak hanya menjadi permasalahan bagi negara berkembang, bahkan negara-negara maju pun mengalami kemiskinan walaupun tidak sebesar Negara berkembang. Persoalannya sama namun dimensinya berbeda. Persoalan kemiskinan di negara maju merupakan bagian terkecil dalam komponen masyarakat mereka tetapi bagi negara berkembang persoalan menjadi lebih kompleks karena jumlah penduduk miskin hampir mencapai setengah dari jumlah penduduk.Bahkan ada negara-negara sangat miskin mempunyai jumlah penduduk miskin melebihi dua pertiga dari penduduknya.Kemiskinan merupakan masalah dalam pembangunan yang bersifat multidimensi.Kemiskinan ditandai oleh keterbelakangan dan pengangguran yang selanjutnya meningkat menjadi pemicu ketimpangan pendapatan dan kesenjangan antar golongan penduduk.

Untuk menanggulangi masalah kemiskinan harus dipilih strategi yang dapat memperkuat peran dan posisi perekonomian rakyat dalam perekonomian nasional, sehingga terjadi perubahan struktural yang meliputi pengalokasian sumber daya, penguatan kelembagaan, pemberdayaan sumber daya manusia.Program yang dipilih harus berpihak dan memberdayakan masyarakat melalui pembangunan ekonomi dan 
peningkatan perekonomian rakyat. Program ini harus diwujudkan dalam langkah-langkah strategis yang diarahkan secara langsung pada perluasan akses masyarakat miskin kepada sumber daya pembangunan dan menciptakan peluang bagi masyarakat paling bawah untuk berpartisipasi dalam proses pembangunan, sehingga mereka mampu mengatasi kondisi keterbelakangannya. Selain itu upaya penanggulangan kemiskinan harus senantiasa didasarkan pada penentuan garis kemiskinan yang tepat dan pada pemahaman yang jelas mengenai sebab-sebab timbulnya persoalan itu.

\section{TINJAUAN PUSTAKA}

\section{Kemiskinan}

Berdasarkan Undang-Undang No. 24 Tahun 2004, kemiskinan adalah kondisi sosial ekonomi seseorang atau sekelompok orang yang tidak terpenuhinya hak-hak dasarnya untuk mempertahankan dan mengembangkan kehidupan yang bermartabat. Kebutuhan dasar yang menjadi hak seseorang atau sekelompok orang meliputi kebutuhan pangan, kesehatan, pendidikan, pekerjaan, perumahan, air bersih, pertanahan, sumber daya alam, lingkungan hidup, rasa aman dari perlakuan atau ancaman tindak kekerasan, dan hak untuk berpartisipasi dalam penyelenggaraan kehidupan sosial dan politik. Laporan Bidang Kesejahteraan Rakyat yang dikeluarkan oleh Kementrian Bidang Kesejahteraan (Kesra) tahun 2004 menerangkan pula bahwa kondisi yang disebut miskin ini juga berlaku pada mereka yang bekerja akan tetapi pendapatannya tidak mencukupi untuk memenuhi kebutuhan pokok/dasar.

Dalam bukunya "mereduksi kemiskinan" menjelaskan bahwa kemiskinan dapat diklasifikasikan berdasarkan beberapa aspek, seperti tingkat keparahan dan penyebab.Berdasarkan tingkat keparahan kemiskinan dapat dibedakan atas kemiskinan absolut dan kemiskinan relatif.Seseorang dikatakan miskin secara absolut apabila tingkat pendapatannya lebih rendah daripada garis kemiskinan absolut. Dengan kata lain jumlah pendapatannya tidak cukup untuk memenuhi kebutuhan hidup minimum yang dicerminkan oleh garis kemiskinan absolut tersebut. (Agussalim; 2000)

Menurut Badan Pusat Statistik, kemiskinan adalah ketidakmampuan memenuhi standar minimum kebutuhan dasar yang meliputi kebutuhan makan maupun non makan. Membandingkan tingkat konsumsi penduduk dengan garis kemiskinan atau jumlah rupiah untuk konsumsi orang perbulan. Sedangkan bagi dinas sosial mendefinisikan 
orang miskin adalah mereka yang sama sekali tidak mempunyai sumber mata pencaharian dan tidak mampu memenuhi kebutuhan dasar mereka yang layak bagi kemanusiaan dan mereka yang sudah mempunyai mata pencaharian tetapi tidak dapat memenuhi kebutuhan dasar yang layak bagi kemanusiaan.

Teori Kemiskinan

Teori pembangunan yakin masalah kemiskinan akan teratasi dengan sendirinya melalui mekanisme pertumbuhan ekonomi. Bahkan Kuznets berpendapat bahwa ketimpangan pendapatan merupakan syarat keharusan bagi pertumbuhan ekonomi yang tinggi.Jadi pada awal pertumbuhan ekonomi tingkat kesenjangan ekonomi makin tinggi sampai pada tingkatan tertentu baru menurun.Teori Harrod-Domar juga menyatakan demikian, dimana untuk pertumbuhan yang tinggi diperlukan akumulasi modal (capital) melalui tabungan (saving).Komponen masyarakat yang mampu menabung adalah kelompok orang kaya, bukan dari kelompok orang miskin.Sehingga pertumbuhan ekonomi hanya dapat dimotori oleh kelompok masyarakat yang mampu memupuk modal. (Todaro; 2002)

Menurut Nurkse dalam kutipan (Lincolin Arshad; 1999) ada dua lingkaran perangkap kemiskinan, yaitu dari segi penawaran (supply) dimana tingkat pendapatan masyarakat yang rendah yang diakibatkan oleh tingkat produktivitas yang rendah menyebabkan kemampuan masyarakat untuk menabung rendah.Kemampuan untuk menabung rendah, menyebabkan tingkat pembentukan modal yang rendah, tingkat pembentukan modal (investasi) yang rendah menyebabkan kekurangan modal, dan dengan demikian tingkat produktivitasnya juga rendah dan seterusnya.Dari segi permintaan (demand), di negara-negara yang miskin perangsang untuk menanamkan modal adalah sangat rendah, karena luas pasar untuk berbagai jenis barang adanya terbatas, hal ini disebabkan oleh karena pendapatan masyarakat sangat rendah.Pendapatan masyarakat sangat rendah karena tingkat produktivitas yang rendah, sebagai wujud dari tingkatan pembentukan modal yang terbatas di masa lalu.Pembentukan modal yang terbatas disebabkan kekurangan perangsang untuk menanamkan modal dan seterusnya.

Indikator kemiskinan bisa ditinjau dari lima sudut, yaitu persentase penduduk miskin, pendidikan (khususnya angka buta huruf), kesehatan (angka kematian bayi dan anak balita kurang gizi), ketenagakerjaan dan ekonomi (konsumsi per kapita). Untuk menentukan seseorang dapat dikatakan miskin atau tidak maka diperlukan tolok ukur yang 
jelas.Berbagai pendekatan atau konsep digunakan sebagai bahan perhitungan dan penentuan batas-batas kemiskinan. (Prihatini; 2006)

Jenis Kemiskinan

Kemiskinan menurut Nurkse (dalam Lincolin Arshad; 1999): Kemiskinan Absolut: Seseorang termasuk golongan miskin absolut apabila hasil pendapatannya berada di bawah garis kemiskinan dan tidak cukup untuk menentukan kebutuhan dasar hidupnya; kemiskinan relatif: Seseorang termasuk golongan miskin relatif apabila telah dapat memenuhi kebutuhan dasar hidupnya, tetapi masih jauh lebih rendah dibandingkan dengan keadaan masyarakat sekitarnya.

Kemiskinan dibagi dalam empat bentuk, yaitu: Kemiskinan absolut, kondiai dimana seseorang memiliki pendapatan di bawah garis kemiskinan atau tidak cukup untuk memenuhi kebutuhan pangan, sandang, papan, kesehatan, perumahan, dan pendidikan yang dibutuhkan untuk bisa hidup dan bekerja; kemiskinan relatif, kondisi miskin karena pengaruh kebijakan pembangunan yang belum menjangkau seluruh masyarakat, sehingga menyebabkan ketimpangan pada pendapatan; kemiskinan kultural, mengacu pada persoalan sikap seseorang atau masyarakat yang disebabkan oleh faktor budaya, seperti tidak mau berusaha memperbaiki tingkat kehidupan, malas, pemboros, tidak kreatif meskipun ada bantuan dari pihak luar; kemiskinan struktural, situasi miskin yang disebabkan oleh rendahnya akses terhadap sumber daya yang terjadi dalam suatu sistem sosial budaya dan sosial politik yang tidak mendukung pembebasan kemiskinan, tetapi seringkali menyebabkan suburnya kemiskinan. (Suryawati; 2005)

Kemiskinan juga dapat dibedakan menjadi dua jenis yaitu: Kemiskinan alamiah, berkaitan dengan kelangkaan sumber daya alam dan prasarana umum, serta keadaan tanah yang tandus serta kemiskinan buatan, lebih banyak diakibatkan oleh sistem modernisasi atau pembangunan yang membuat masyarakat tidak mendapat menguasai sumber daya, sarana, dan fasilitas ekonomi yang ada secara merata. (Suryawati; 2005)

Ukuran Kemiskinan

Bank Dunia membantu Badan Koordinasi Keluarga Berencana Nasional (BKKBN) mengukur kemiskinan berdasarkan pada pendapatan seseorang. Seseorang yang memiliki pendapatan kurang dari US\$ 1 per hari masuk dalam kategori miskinUntuk mengukur kemiskinan, Indonesia melalui BPS menggunakan pendekatan kebutuhan dasar (basic needs) yang dapat diukur dengan angka atau hitungan Indeks Perkepala (Head Count Index), yakni jumlah dan persentase penduduk miskin yang berada di 
bawah garis kemiskinan. Garis kemiskinan ditetapkan pada tingkat yang selalu konstan secara riil sehinga kita dapat mengurangi angka kemiskinan dengan menelusuri kemajuan yang diperoleh dalam mengentaskan kemiskinan di sepanjang waktu.

Mengukur kemiskinan berdasarkan dua kriteria, yaitu: Kriteria Keluarga Pra Sejahtera (Pra KS) yaitu keluarga yang tidak mempunyai kemampuan untuk menjalankan perintah agama dengan baik, minimum makan dua kali sehari, membeli lebih dari satu stel pakaian perorang per tahun, lantai rumah bersemen lebih dari $80 \%$, dan berobat ke Puskesmas bila sakit. Kriteria Keluarga Sejahtera 1 (KS 1) yaitu keluarga yang tidak berkemampuan untuk melaksanakan perintah agama dengan baik, minimal satu kali per minggu makan daging/telor/ikan, membeli pakaian satu stel per tahun, rata-rata luas lantai rumah 8 meter per segi per anggota keluarga, tidak ada anggota keluarga umur 10 sampai 60 tahun yang buta huruf, semua anak berumur antara 5 sampai 15 tahun bersekolah, satu dari anggota keluarga mempunyai penghasilan rutin atau tetap, dan tidak ada yang sakit selama tiga bulan. (Suryawati, 2005). Pendekatan dalam pengukuran kemiskinan dengan strategi kebutuhan dasar (basic needs) yang dipromosikan dan dipopulerkan oleh International Labor Organization (ILO) pada tahun 1976 dengan judul "Kesempatan Kerja, Pertumbuhan Ekonomi, dan Kebutuhan Dasar: Suatu Masalah bagi Satu Dunia". Strategi kebutuhan dasar memang memberi tekanan pada pendekatan langsung dan bukan cara tidak langsung seperti melalui efek menetes ke bawah (trickel-down effect) dari pertumbuhan ekonomi yang tinggi. Kesulitan umum dalam penentuan indikator kebutuhan dasar adalah standar atau kriteria yang subjektif karena dipengaruhi oleh adat, budaya, daerah, dan kelompok sosial.Disamping itu kesulitan penentuan secara kuantitatif dari masing-masing komponen itu sendiri, misalnya selera konsumen terhadap suatu jenis makanan atau komoditi lainnya.

\section{Pertumbuhan Ekonomi}

Pertumbuhan ekonomi adalah kenaikan kapasitas dalam jangka panjang dari negara yang bersangkutan untuk menyediakan berbagai barang ekonomi kepada penduduknya yang ditentukan oleh adanya kemajuan atau penyesuaian teknologi, institusional (kelembagaan), dan ideologis terhadap berbagai tuntutan keadaan yang ada Simon Kuznetz dalam (Todaro; 2002).

Menurut Boediono, pertumbuhan ekonomi adalah proses kenaikan output per kapita dalam jangka panjang. Pertumbuhan ekonomi berkaitan 
dengan kenaikan output per kapita dimana ada dua sisi yang perlu diperhatikan, yaitu sisi output totalnya (GDP) dan sisi jumlah penduduknya. Output per kapita adalah output total dibagi dengan jumlah penduduk.

Menurut Kuznet dalam kutipan (Todaro; 2003) pertumbuhan ekonomi adalah kenaikan kapasitas dalam jangka panjang dari negara bersangkutan untuk menyediakan berbagai barang ekonomi kepada penduduknya.Kenaikan kapasitas ditentukan oleh kemajuan atau penyesuaian teknologi, institusional, dan ideologis terhadap tuntutan keadaan yang ada. Kuznets sangat menekankan pada perubahan dan inovasi teknologi sebagai cara meningkatkan pertumbuhan produktivitas terkait dengan redistribusi tenaga kerja dari sektor yang kurang produktif (yaitu pertanian) ke sektor yang lebih produktif (yaitu industri manufaktur).

\section{Teori Pertumbuhan Ekonomi}

Teori pertumbuhan ekonomi pada awalnya diprakarsai oleh Ricardo dan Malthus yang mencoba menganalisis perekonomian di Inggris, meskipun banyak memperoleh kritikan namun pada pertengahan abad ke 20 teori pertumbuhan berkembang dalam tiga gelombang. Gelombang pertama digagasi oleh (Harrod; 1993 dan 1948) dan (Domar; 946 dan 1947), kemudian gelombang kedua diprakarsai oleh Solow dengan teori Neoclasical model of economic growth (1956) dan Swan pada pertengahan tahun 1950. Selanjutnya gelombang ketiga di kemukakan oleh (Romer dan Lucas; 1988).

Kedua ahli ekonomi klasik ini berbeda sekali padangannya dengan Adam Smith yang optimis.Ricardo dan Malthus justru pesimis. Dalam jangka panjang menurutnya perekonomian justru akan mengalami apa yang dinamakan stationary state, yaitu suatu keadaan dimana perkembangan ekonomi tidak terjadi sama sekali. Adapun berbedaan pandangan antara Adam Smith dan kedua ahli tersebut disebabkan adanya pandangan yang berbeda mengenai peranan penduduk dalam pembangunan ekonomi. (Todaro; 2003)

Menurut Ricardo dan Malthus, perkembangan penduduk yang berjalan dengan cepat akan memperbedar jumlah penduduk hingga dua kali lipat dalam waktu satu generasi, yang nantinya hal tersebut akan menurunkan kembali tingkat pembangunan ke taraf yang lebih rendah. Pada tingkat ini pekerja akan menerima upah yang hanya cukup untuk hidup (subsistance level). Apabila yang dibicarakan mengenai teori pertumbuhan dari klasik, maka yang dimaksud adalah teori pertumbuhan 
dari Ricardo yang sangat dipengaruhi teori perkembangan penduduk dari Malthus dan teori hasil lebih yang semakin berkurang. (Todaro; 2003)

Teori pertumbuhan Harrod-Domar ini dikembangkan setelah Keynes, yang mempunyai asumsi yaitu : perekonomian dalam keadaan pengerjaan penuh (full employment) dan barang-barang modal dalam masyarakat digunakan secara penuh; perekonomian 2 sektor yaitu sektor rumah tangga dan sektor perusahaan; besarnya tabungan masyarakat adalah proporsional dengan besarnya pendapatan nasional, fungsi tabungan dimulai dari titik nol \& kecenderungan untuk menabung (marginal propensity to save) besarnya tetap, ratio antara modal output (capital output ratio ) dan rasio pertambahan modal-output (incremental capitaloutput ratio). Dalam teori ini disebutkan, bahwa jika ingin tumbuh, perekonomian harus menabung dan menginvestasikan suatu proporsi tertentu dari output totalnya. Semakin banyak tabungan dan kemudian di investasikan, maka semakin cepat perekonomian itu akan tumbuh. (Todaro; 2003).

Teori pertumbuhan Neo Klasik, dikembangkan oleh (Solow; 1956) berdasarkan teori-teori klasik sebelumnya yang telah disempurnakannya.Laju tingkat pertumbuhan yang dapat dicapai suatu negara tergantung kepada tingkat perkembangan teknologi, peranan modal dalam menciptakan pendapatan negara (produksi marjinal modal) dikalikan dengan tingkat perkembangan stok modal, serta peranan tenaga kerja dalam menciptakan pendapatan negara (produktivitas marjinal tenaga kerja) dikalikan dengan tingkat pertambahan tenaga kerja. Pertumbuhan output selalu bersumber dari satu atau lebih dari tiga faktor yakni kenaikan kualitas dan kuantitas tenaga kerja, penambahan modal (tabungan dan investasi) dan penyempurnaan teknologi. (Todaro, 2003)

Teori pertumbuhan endogen yang dipelopori oleh Romer (1986) dan Lucas (1988) merupakan awal kebangkitan dari pemahaman baru mengenai faktor-faktor yang menentukan pertumbuhan ekonomi dalam jangka panjang. Hal ini seiring dengan perkembangan dunia yang ditandai oleh perkembangan tehnologi modern yang digunakan dalam proses produksi. Sehingga permasalahan dalam pertumbuhan ekonomi tidak bisa dijelaskan secara baik oleh teori Neoklasik, seperti penjelasan mengenai decreasing return to capital, persaingan sempurna dan eksogenitas tehnologi dalam model pertumbuhan ekonomi. Teori Pertumbuhan endogen merupakan suatu teori pertumbuhan yang menjelaskan bahwa pertumbuhan dalam jangka panjang ditentukan dari dalam model dari pada oleh beberapa variabel pertumbuhan yang dianggap eksogen (Romer, 
1994:3; Barro dan Martin,1999:38). Teori pertumbuhan endogen muncul sebagai kritik terhadap teori pertumbuhan Neoklasik mengenai diminishing marginal productivity of capital dan konvergenitas pendapatan di berbagai negara.Romer (1986) mengembangkan model pertumbuhan endogen sebagai akibat dari adanya knowledge externality. Suatu perusahaan dapat lebih produktif dai perusahaan lain karena perusahaan tersebut mempunyai rata-rata stock knowledge yang lebih tinggi dari pada perusahaan lainnya. (Todaro, 2003).

\section{Ukuran Pertumbuhan Ekonomi}

Pengukuran akan kemajuan sebuah perekonomian memerlukan alat ukur yang tepat, beberapa alat pengukur pertumbuhan ekonomi antara lain yaitu : Produk Domestik Bruto (PDB) di tingkat secara regional disebut Produk Domestik Regional Bruto (PDRB), merupakan jumlah barang dan jasa akhir yang dihasilkan oleh suatu perekonomian dalam satu tahun dan dinyatakan dalam harga pasar. Produk Domestik Bruto Per kapita/Pendapatan Per kapita Produk Domestik Bruto dapat digunakan sebagai pengukur pertumbuhan ekonomi yang lebih baik karena lebih tepat mencerminkan kesejahteraan penduduk suatu negara daripada nilai PDB atau PDRB saja. Produk domestik bruto per kapita baik di tingkat nasional maupun di daerah adalah jumlah PDB nasional atau PRDB suatu daerah dibagi dengan jumlah penduduk di Negara maupun di daerah yang bersangkutan, atau dapat disebut juga sebagai PDB atau PDRB rata-rata. (Nugraheni; 2001)

\section{Faktor Yang Mempengaruhi Pertumbuhan Ekonomi}

Menurut pandangan ekonomi klasik mengemukakan bahwa pada dasarnya ada empat faktor yang mempengaruhi pertumbuhan ekonomi, yaitu jumlah penduduk; jumlah stok barang dan modal; luas tanah dan kekayaan alam serta tingkat teknologi yang digunakan. (Kuncoro; 2004)

Ada tiga faktor utama dalam pertumbuhan ekonomi, yaitu: 1) Akumulasi modal akan terjadi jika ada sebagian dari pendapatan sekarang di tabung yang kemudian diinvestasikan kembali dengan tujuan untuk memperbesar output di masa-masa mendatang. Akumulasi modal merupakan semua investasi yang berwujud berupa: tanah (lahan), peralatan fiskal, dan sumber daya manusia (human resources), serta investasi infrastruktur, yakni berupa jalan, listrik, air bersih, fasilitas sanitasi, fasilitas komunikasi, demi menunjang aktivitas ekonomi produktif. 2) Pertumbuhan penduduk memiliki hubungan dengan kenaikan jumlah 
angkatan kerja secara tradisional telah dianggap sebagai faktor yang positif dalam merangsang pertumbuhan ekonomi. Artinya, semakin banyak angkatan kerja semakin produktif tenaga kerja, sedangkan semakin banyak penduduk akan meningkatkan potensi pasar domestik. 3) Kemajuan teknologi disebabkan oleh adanya perubahan teknologi lama diubah menjadi teknologi baru. Ada 3 klasifikasi kemajuan teknologi, yakni Kemajuan teknologi yang bersifat netral, terjadi jika tingkat output yang dicapai lebih tinggi pada kuantitas dan kombinasi-kombinasi input yang sama; Kemajuan teknologi yang bersifat hemat tenaga kerja (labor saving) atau hemat modal (capital saving), yaitu tingkat output yang lebih tinggi bisa dicapai dengan jumlah tenaga kerja atau input modal yang sama; serta Kemajuan teknologi yang meningkatkan modal, terjadi jika penggunaan teknologi tersebut memungkinkan kita memanfaatkan barang modal yang ada secara lebih produktif. (Todaro; 2003)

\section{Konsep Pendapatan}

Tolak ukur yang paling banyak dipakai untuk mengukur keberhasilan sebuah perekonomian antara lain pendapatan nasional,produk nasional,tingkat kesempatan kerja,tingkat harga,dan posisi neraca pembayaran luar negeri. Salah satu terjadinya alokasi yang efisien secara makro adalah nilai output nasional yang dihasilkan sebuah perekonomian pada suatu periode tertentu. Sebab,besarnya output nasional dapat menununjukkan hal penting dalam sebuah perekonomian. Pertama,besarnya output nasional merupakan gambaran awal seberapa efisien sumber-sumber daya yang ada dalam perekonomian (tenaga kerja,barang modal,uang,dan kemampuan kewirausahaan) digunakan untuk memproduksi barang dan jasa. Maka semakin besar pendapatan nasional suatu negara, semakin baik efisiensi alokasi sumber daya ekonominya; besarnya output nasional merupakan gambaran awal tentang produktivitas dan tingkat kemakmuran suatu negara.

Dimana alat ukur yang dipakai untuk mengukur kemakmuran adalah output nasional perkapita. Nilai output perkapita diperoleh dengan cara membagi besarnya output nasional dengan jumlah penduduk pada tahun yang bersangkutan. Jika angka output pendapatan semakin besar,maka tingkat kemakmuran dianggap semakin tinggi; besarnya output nasional merupakan gambaran awal tentang masalah-masalah struktural yang (mendasar) yang dihadapi suatu perekonomian. Jika sebagian besar output nasional dinikmati oleh sebagian kecil penduduk maka 
perekonomian tersebut mempunyai masalah dengan distribusi pendapatannya.

Produk Domestik Ragional Bruto (PDRB)

Pendapatan regional adalah tingkat (besarnya) pendapatan masyarakat pada wilayah analisis.Menganalisis suatu region atau membicarakan pembangunan regional tidak mungkin terlepas dari membahas tingkat pendapatan wilayah maupun pendapatn rata-rata masyarakat pada wilayah tersebut.Pembangunan wilayah haruslah bersangkut paut dengan peningkatan pendapatan masyarakat di wilayah tersebut, yaitu yang dimaksud adalah pendapatan rata-rata (income per capita) masyarakat. (Tarigan;2005)

Produk Domestik ragional Bruto (PDRB) adalah jumlah seluruh nilai produk barang dan jasa yang dihasilkan oleh unit-unit produksi yang beroperasi pada suatu daerah dalam jangka waktu tertentu. Atau apabila ditinajau dari segi pendapatan merupakan jumlah dari pendapatan yang diterima oleh faktor- faktor produksi yang dimiliki oleh penduduk di wilayah tersebut yang ikut serta dalam proses produksi dalam jangka waktu tertentu. Hasil perhitungan PDRB disajikan atas PDRB atas dasar harga berlaku menggambarkan nilai tambah barang dan jasa yang dihitung dengan menggunakan harga pada setiap tahun dan memasukkan nilai inflasi, sedangkan PDRB atas dasar harga konstan menunjukan nilai tambah barang dan jasa yang dihitung menggunakan harga pada satu tahun tertentu sebagai tahun dasar penghitungannya dan tidak memasukkan nilai inflasi. (Hadibroto, dkk; 1975)

Ada beberapa cara lain yang lazim digunakan dalam perhitungan pendapatan suatu daerah yakni: 1) Pendekatan Produksi (Production Approach) adalah jumlah Nilai Tambah Bruto (NTB) atau nilai barang dan jasa akhir yang dihasilkan oleh unit-unit produksi di suatu wilayah/region dalam suatu periode tertentu, biasanya satu tahun. NTB adalah Nilai Produksi Bruto (NPB/Output) dari barang dan jasa tersebut dikurangi seluruh biaya antara yang digunakan dalam proses produksi; 2) Pendekatan Pendapatan (Income Approach) adalah jumlah seluruh balas jasa yang diterima oleh faktor-faktor produksi yang ikut serta dalam proses produksi di suatu wilayah/region dalam jangka waktu tertentu, biasanya satu tahun. Berdasarkan pengertian tersebut maka NTB adalah jumlah dari upah dan gaji, sewa tanah, bunga modal dan keuntungan; semuanya sebelum dipotong pajak penghasilan dan pajak langsung lainnya; 3) Pendekatan Pengeluaran (Expenditure Approach) adalah jumlah seluruh pengeluaran yang dilakukan untuk pengeluaran konsumsi rumahtangga dan lembaga 
swasta nirlaba, pengeluaran konsumsi pemerintah, pembentukan modal tetap domestik bruto dan ekspor neto (ekspor neto merupakan ekspor dikurangi impor), di dalam suatu wilayah/region dalam periode tertentu, biasanya satu tahun. (Hadibroto, dkk; 1975)

\section{Pendapatan Perkapita}

Pendapatan regional per kapita atau PDRB per kapita adalah besarnya pendapatan rata-rata penduduk di suatu negara.Pendapatan perkapita didapatkan dari hasil pembagian pendapatan nasional suatu negara dengan jumlah penduduk negara tersebut.Pendapatan perkapita juga merefleksikan pendapatan perkapita.PDRB perkapita sering digunakan sebagai tolak ukur kemakmuran dan tingkat pembangunan sebuah negara semakin besar pendapatan perkapitanya, semakin makmur negara tersebut. (Wikipedia; 2011)

Sebagai indikator ekonomi yang mengukur tingkat kemakmuran penduduk suatu negara, pendapatan per kapita di hitung secara berkala (Periodik) biasanya satu tahun. Manfaat dari perhitungan pendapatan perkapita antara lain adalah sebagai berikut : 1) Untuk melihat tingkat perbandingan kesejahteraan masyarakat suatu negara dari tahun ke tahun; 2) Sebagai data pebandingan kesejahteraan suatu negara dengan negara lain. Dari pendapatan per kapita masing-masing negara dapat di lihat tingkst kesejahteraan tiap Negara; 3) Sebagai perbandingan tingkat standar hidup suatu negara dengan negara lainnya.Dengan mengambil dasar pendapatan perkapita dari tahun ke tahun, dapat di simpulkan apakah pendapatan per kapita suatu negara rendah (bawah), sedang atau tinggi dan 4) Sebagai data untuk mengabil kebijakan di bidang ekonomi.Pendapatan per kapita dapat di gunakan sebagai bahan pertimbangan untuk mengambil langkah di bidang ekonomi. (Wikipedia; 2011)

Menurut (Todaro; 2003) PDRB per kapita merupakan ukuran kemajuan pembangunan. Pembangunan bertujuan untuk meningkatkan pendapatan masyarakatnya sehingga pertumbuhan pendapatan menjadi tolok ukur kemajuan pembangunan

Menurut Sumitro dalam (Ginting; 2008) menyatakan bahwa pembangunan ekonomi sebagai usaha untuk memperbesar pendapatan perkapita sebagai tolak ukur dalam menentukan pembangunan ekonomi yang dapat menaikkan produktifitas perkapita dengan jalan menambah peralatan modal dan menambah keterampilan.Dengan demikian pembangunan ekonomi berarti peningkatan kesejahteraan masyarakat dengan peningkatan pendapatan perkapita. 


\section{Inflasi}

Dalam ilmu ekonomi, inflasi adalah suatu proses meningkatnya harga-harga secara umum yang berkaitan dengan mekanisme pasar yang dapat disebabkan oleh berbagai faktor, antara lain, konsumsi masyarakat yang meningkat, berlebihnya likuiditas di pasar yang memicu konsumsi atau bahkan spekulasi, sampai termasuk juga akibat adanya ketidaklancaran distribusi barang. Inflasi dapat digolongkan menjadi empat golongan, yaitu inflasi ringan, sedang, berat, dan hiperinflasi. Inflasi ringan terjadi apabila kenaikan harga berada di bawah angka $10 \%$ setahun; inflasi sedang antara 10\%-30\% setahun; berat antara 30\%-100\% setahun; dan hiperinflasi atau inflasi tak terkendali terjadi apabila kenaikan harga berada di atas $100 \%$ setahun. (Wikipedia; 2011)

Inflasi merupakan kenaikan harga secara terus menerus dan kenaikan harga yang terjadi pada seluruh kelompok barang dan jasa.Bahkan mungkin dapat terjadi kenaikan tersebut tidak bersamaan.Yang penting kenaikan harga umum barang secara terus menerus selama suatu periode tertentu.(Pohan; 2008).

(Venieris dan Seblod; 1978) mendefeniskan inflasi sebagai suatu kecenderungan meningkatnya tingkat harga umum secara terus menerus sepanjang waktu (a sustained tedency for the general level of prices to rise over time). Sedangkan Pengertian inflasi menurut (Boediono; 1982) inflasi adalah Kecenderungan harga- harga naik secara umum dan terus menerus, kenaikan harga dari satu atau dua barang saja tidak disebut inflasi kecuali kenaikan tersebut meluas kepada (atau mengakibatkan kenaikan) sebagian besar dari harga- harga barang lain.

Jenis-Jenis Inflasi

Secara umum ada tiga jenis indeks harga yaitu : Indeks Harga Konsumen (INK) adalah suatu indeks harga yang mengukur biaya sekelompok barang dan jasa di pasar termasuk harga- harga makanan pakaian, perumahan, transportasi, perawatan, kesehatan, dan komoditi lain yang dibeli untuk menunjang kehidupan sehari- hari; Indeks Harga Produsen (IHP) adalah suatu indeks dari harga bahan-bahan baku, produk antara peralatan modal,, dan mesin yang dibeli oleh sektor bisnis atau perusahaan; serta GNP Deflator adalah suatu indeks yang merupakan perbandingan atau rasio antara GNP nominal dan GNP riil dikalikan dengan 100. GNP rill adalah nilai barang dan jasa yang dihasilkan dalam perekonomian, yang diperoleh ketika output dinilai dengan menggunakan harga tahun dasar, Sedangkan GNP nominal adalah GNP yang dihitung berdasarkan harga berlaku. (Nanga; 2001) 
Laju inflasi dapat berbeda antara satu negara dengan negara lain atau dalam negara satu untuk waktu yang berbeda. Atas dasar jenisnya, inflasi dibagi dalam tiga kategori: Inflasi Merayap (Creeping inflation), yatiu inflasi yang ditandai dengan laju inflasi yang rendah kurang dari $10 \%$ per tahun. kenaikan harga berjalan secara lambat dengan persenmtase kecil serta dalam jangka waktu yang relatif lama; Inflasi Menegah (Galloping Inflation), (Randal dengan kenaikan harga yang cukup besar, biasanya sampai double digit atau triple digit dan kadang kala berjalan dalam waktu yang relatif pendek serta mempunyai sifat akselerasi; Inflasi Tinggi (Hyper inflation) merupakan inflasi yang paling parah akibatnya. Harga- harga naik sampai 5 atau 6 kali. (Nopirin; 1987)

Teori Inflasi

Inflasi adalah keadaan di mana terjadi kelebihan permintaan (Excess Demand) terhadap barang-barang dalam perekonomian secara keseluruhan.Inflasi sebagai suatu kenaikan harga yang terus menerus dari barang dan jasa secara umum (bukan satu macam barang saja dan sesaat).Inflasi dapat mempengaruhi distribusi pendapatan, alokasi faktor produksi serta produk nasional.Efek terhadap distribusi pendapatan disebut dengan equity effect, sedangkan efek terhadap alokasi faktor produksi dan pendapatan nasional masing-masing disebut dengan efficiency dan output effects. (Nopirin; 2000)

Disamping itu menurut (Greene dan Pillanueva; 2001), tingkat inflasi yang tinggi sering dinyatakan sebagai ukuran ketidakstabilan roda ekonomi makro dan suatu ketidakmampuan pemerintah dalam mengendalikan kebijakan ekonomi makro. Di Indonesia kenaikan tingkat inflasi yang cukup besar biasanya akan diikuti dengan kenaikan tingkat suku bunga perbankan. Inflasi dapat menyebabkan terjadinya kenaikan produksi.Alasanya dalam keadaan inflasi biasanya kenaikan harga barang mendahului kenaikan upah, sehingga keuntungan perusahaan naik.Namun apabila laju inflasi itu cukup tinggi (Hiper Inflasi) dapat mempunyai akibat sebaliknya, yaitu penurunan output. Dalam keadaan inflasi yang tinggi nilai uang riil turun dengan drastis, masyarakat cenderung tidak mempunyai uang kas, transaksi mengarah ke barter, yang biasanya diikuti dengan turunya produksi barang. Inflasi bisa dibarengi dengan kenaikan output, tetapi bias juga dibarengi dengan penurunan output. Tetapi dalam keadaan yang pernah terjadi biasanya nilai inflasi lebih besar akan menaikkan output, dan itu akan membuat pengusaha atau perusahaan untuk berinvestasi atau menanamkan modal mereka.

Penyebab Inflasi 
Ada beberapa faktor yang menyebabkan timbulnya inflasi: Demand Pull Inflation. Timbul terjadi akibat adanya permintaan total yang berlebihan dimana biasanya dipicu oleh membanjirnya likuiditas di pasar sehingga terjadi permintaan yang tinggi dan memicu perubahan pada tingkat harga. Bertambahnya volume alat tukar atau likuiditas yang terkait dengan permintaan terhadap barang dan jasa mengakibatkan bertambahnya permintaan terhadap faktor-faktor produksi tersebut; Cost Push Inflation terjadi akibat adanya kelangkaan produksi dan/atau juga termasuk adanya kelangkaan distribusi, walau permintaan secara umum tidak ada perubahan yang meningkat secara signifikan.Adanya ketidak-lancaran aliran distribusi ini atau berkurangnya produksi yang tersedia dari rata-rata permintaan normal dapat memicu kenaikan harga sesuai dengan berlakunya hukum permintaan-penawaran, atau juga karena terbentuknya posisi nilai keekonomian yang baru terhadap produk tersebut akibat pola atau skala distribusi yang baru. (Samuelson dan Nordhaus; 2004)

Sedangkan faktor- faktor yang menyebabkan timbulnya inflasi tidak hanya dipengaruhi oleh Demand Pull Inflation dan Cost Push Inflation tetapi juga dipengaruhi oleh : 1) Inflasi yang berasal dari dalam negeri (Domestic Inflation) yaitu inflasi yang disebabkan adanya peristiwa ekonomi dalam negeri, misalnya terjadi defisit anggaran belanja negara yang secara terus-menerus, kemudian pemerintah memerintahkan Bank Indonesia untuk mencetak uang baru dalam jumlah besar; 2) Inflasi yang tertular dari luar negeri (Imported Inflation) yaitu penularan melalui harga barang impor. Inflasi ini umumnya terjadi di negara berkembang yang mana sebagaian besar bahan baku dan peralatan dalam unit produksinya berasal dari luar negeri. (Samuelson dan Nordhaus; 2004)

Masalah inflasi adalah masalah yang terus-menerus mendapat perhatian pemerintah.Adapun yang menjadi tujuan jangka panjang pemerintah adalah menjaga agar tingkat inflasi yang berlaku pada tingkat yang sangat rendah.Inflasi diukur dengan menghitung perubahan tingkat persentase perubahan sebuah indeks harga. (Sadono,Sukimo; 2006).

\section{Pengangguran}

Pengangguran atau tuna karya adalah istilah untuk orang yang tidak bekerja sama sekali, sedang mencari kerja, bekerja kurang dari dua hari selama seminggu, atau seseorang yang sedang berusaha mendapatkan pekerjaan yang layak. Pengangguran umumnya disebabkan karena jumlah angkatan kerja atau para pencari kerja tidak sebanding dengan jumlah lapangan kerja yang ada yang mampu menyerapnya. 


\section{Hubungan Variabel}

\subsection{Hubungan Pertumbuhan Ekonomi Dengan Kemiskinan}

Hubungan antara pertumbuhan ekonomi, kemiskinan, dan ketimpangan telah banyak dilakukan di indonesia. Hasil studi terbaru menemukan bahwa: a) Terdapat hubungan negatif yang sangat kuat antara pertumbuhan dan kemiskinan. artinya ketika perekonomian tumbuh, kemiskinan berkurang. Namun ketika perekonomian mengalami kontraksi pertumbuhan, kemiskinan meningkat lagi, b) Pertumbuhan tidak mengurangi kemiskinan secara permanen. Walaupun terjadi pertumbuhan dalam jangka panjang selama periode sebelum krisis, banyak masyarakat yang tetap rentan terhadap kemiskinan, c) Pertumbuhan secara kontemporer dapat mengurangi kemiskinan sehingga pertumbuhan yang berkelanjutan penting untuk mengurangi kemiskinan, d) Pengurangan ketimpangan mengurangi kemiskinan secara signifikan sehingga sangat penting untuk mencegah pertumbuhan yang meningkatkan ketimpangan, e) Memberikan hak atas properti dan memberikan akses terhadap kapital untuk golongan masyarakat miskin dapat mengurangi kesenjangan, merangsang pertumbuhan, dan mengurangi kemiskinan.

\subsection{Hubungan PDRB Per Kapita terhadap Kemiskinan}

Pembangunan ekonomi mensyaratkan pendapatan nasional yang lebih tinggi dan untuk itu tingkat pertumbuhan yang lebih tinggi merupakan pilihan yang harus diambil.Namun yang menjadi permasalahan bukan hanya soal bagaimana cara memacu pertumbuhan, tetapi juga siapa yang melaksanakan dan berhak menikmati hasilnya. Produk Domestik ragional Bruto (PDRB) adalah jumlah seluruh nilai produk barang dan jasa yang dihasilkan oleh unit-unit produksi yang beroperasi pada suatu daerah dalam jangka waktu tertentu. Atau apabila ditinajau dari segi pendapatan merupakan jumlah dari pendapatan yang diterima oleh faktor- faktor produksi yang dimiliki oleh penduduk di wilayah tersebut yang ikut serta dalam proses produksi dalam jangka waktu tertentu. Hasil perhitungan PDRB disajikan atas dasar harga berlaku dan harga konstan. Perhitungan atas dasar berlaku (at currebnt Prince) merupakan jumlah seluruh nilai barang dan jasa akhir yang dihasilkan oleh unit-unit produksi di dalam suatu periode tertentu, biasanya dalam satu tahun yang dinilai dengan harga tahun yang bersangkutan. Pada perhitungan atas dasar harga berlaku belum menghilangkan faktor inflasi, jadi faktor inflasi masih terdapat didalamnya. Pendapatan perkapita merupakan gamabaran rata-rata pendapatan yang diterima oleh penduduk sebagai hasil dari proses 
produksi. Pendapatan perkapita sering menjadi tolak ukur kemakmuran suatu negara atau daerah. Pendapatan perkapita pada dasarnya mengukur kemampuan dari suatu Negara.

\subsection{Hubungan Inflasi Dengan Kemiskinan}

Inflasi adalah kecenderungan dari harga-harga untuk menaik secara umum dan terus menerus. Kenaikan harga dari satu atau dua barang saja tidak disebut inflasi, kecuali bila kenaikan tersebut meluas kepada (atau mengakibatkan kenaikan) sebagian besar dari harga barang-barang lain. Akibat buruk yang paling nyata dari inflasi ialah kemerosotan pendapatan riil yang diterima masyarakat. Pendapatan pekerja-pekerja tidak selalu mengalami perubahan untuk menyesuaikan dengan keadaan inflasi. Dengan demikian inflasi akan menurunkan pendapatan riil dari pekerjapekerja berpendapatan tetap. Di samping itu inflasi dapat menimbulkan berbagai akibat buruk atas kegiatan dalam perekonomian yang pada akhirnya akan menimbulkan ketidakstabilan, pertumbuhan yang lambat dan pengangguran yang semakin meningkat (Sukirno, 2004).

\subsection{Hubungan Pengangguran Dengan Kemiskinan}

Tenaga kerja adalah setiap orang laki-laki atau perempuan yang sedang dalam dan/atau akan melakukan pekerjaan, baik di dalam maupun di luar hubungan kerja guna menghasilkan barang atau jasa untuk memenuhi kebutuhan masyarakat. Salah satu faktor penting yang menentukan kemakmuran masyarakat adalah tingkat pendapatan. Pendapatan masyarakat mencapai maksimum apabila tingkat penggunaan tenaga kerja penuh dapat terwujud, sehingga apabila tidak bekerja atau menganggur maka akan mengurangi pendapatan dan hal ini akan mengurangi tingkat kemakmuran yang mereka capai sehingga dapat menimbulkan buruknya kesejahteraan masyarakat (Sukirno, 2004). 


\section{Kerangka Berpikir}

Adapun kerangka berpikirnya adalah sebagai berikut :

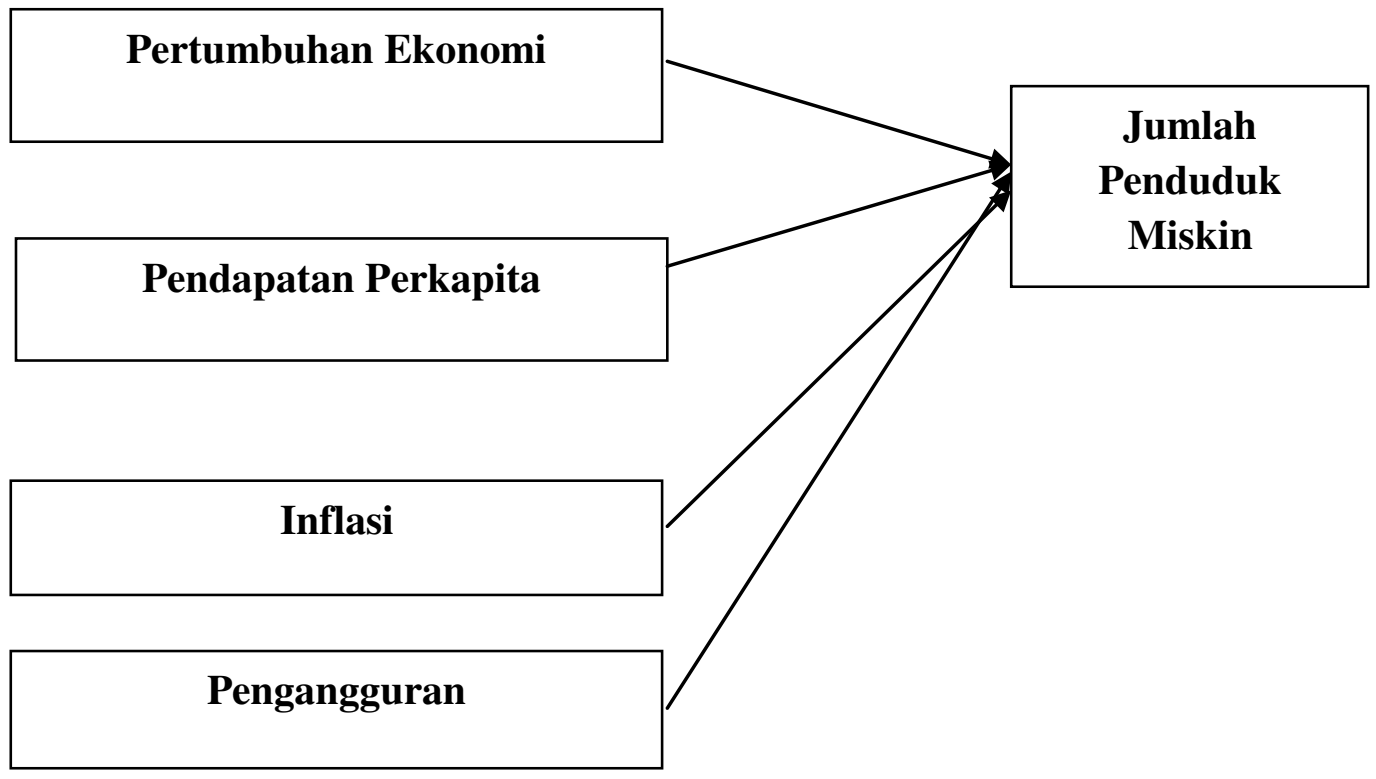

Pada kerangka diatas dijelaskan bahwa tingkat kemiskinan dipengaruhi oleh beberapa faktor yaitu pertumbuhan ekonomi, pendapatan perkapita, inflasi dan Pengangguran. Dalam indikator makro ekonomi ada yang menjadi pokok permasalahan yang terkait dengan masalah kemiskinan, yaitu : masalah pertumbuhan ekonomi dapat dikategorikan pada angka pertumbuhan ekonominya baik secara positif dan negatif. Masalah ekonomi yang perlu diperhatikan seiring dengan adanya peningkatan pendapatan per kapita adalah permasalahan kemiskinan, gejolak harga/inflasi, pengangguran.Perekonomian yang baik harus mengalami pergerakan yang bersinergi antara PDRB per kapita dengan permasalahan ekonomi lainnya. Dalam artian, peningkatan PDRB per kapita harus dibarengi dengan penurunan angka kemiskinan, pengangguran dan inflasi yang dapat ditekan.Masalah Inflasi merupakan indikator perubahan harga barang-barang dan jasa-jasa pada umumnya, yang secara bersamaan juga berkaitan dengan kemampuan daya beli.Inflasi mencerminkan stabilitas harga dan stabilitas ekonomi.Semakin rendah tingkat inflasi berarti semakin stabil pula harga dan perekonomian suatu negara.Namun masalah inflasi tidak hanya berkaitan dengan melonjaknya harga barang-barang dan jasa-jasa.Inflasi juga berkaitan dengan 
purchasing power (daya beli) dari masyarakat.Sementara daya beli masyarakat ditentukan oleh upah.

Masalah pengangguran harus diperhatikan terutama bagi negaranegara yang sedang berkembang seperti Indonesia.Negara berkembang sering kali dihadapkan dengan besarnya angka pengangguran, karena sempitnya kesempatan kerja dan besarnya jumlah penduduk.

\section{Hipotesis}

Hipotesis adalah jawaban sementara atas masalah yang telah dirumuskan. Dari penjelasan teori dan perumusan masalah diatas, maka Hipotesis dirumuskan sebagai berikut :

Pertumbuhan Ekonomi, Pendapatan Perkapita, Inflasi dan Pengangguran mempengaruhi Jumlah Penduduk Miskin di Sumatera Utara

\section{METODE PENELITIAN}

\section{Populasi dan Sampel}

Menurut Arikunto (2010) bahwa populasi adalah seluruh objek yang akan diteliti. Populasi dalam penelitian ini adalah Pertumbuhan Ekonomi, Pendapatan Perkapita, Inflasi, Pengangguran dan Jumlah Penduduk Miskin di Sumatera Utara.Sampel adalah sebahagian atau wakil dari populasi yang menjadi objek penelitian. Sampel dalam penelitian adalah data Pertumbuhan Ekonomi, Pendapatan Perkapita, Inflasi, Pengangguran dan Jumlah Penduduk Miskin di Sumatera Utara dari periode tahun 2003 sampai 2014.

\section{Operasionalisasi Variabel}

Variabel penelitian adalah suatu atribut atau sifat atau nilai dari orang atau objek yang mempunyai variasi antara satu dengan yang lainnya dalam kelompok itu (Sugiyono,2011). Variabel-variabel yang dipakai dalam penelitian ini sebagai berikut :

1. Pertumbuhan ekonomi adalah terjadinya perubahan atau pertambahan pendapatan nasional dalam PDB pada harga konstan yang dinyatakan dalam satuan Persen.

2. Pendapatan regional per kapita atau PDRB per kapita adalah jumlah PDRB suatu daerah dibagi dengan jumlah penduduk yang bersangkutan. Satuan variable PDRB per kapita dalam penelitian ini adalah satuan Rupiah.

3. Inflasi adalah kenaikan harga secara umum, atau Inflasi dapat juga dikatakan sebagai penurunan daya beli uang. 
4. Pengangguran yaitu, penduduk yang termasuk angkatan kerja namun tidak melakukan pekerjaan atau sedang mencari pekerjaan yang dinyatakan dalam satuan Persen.

5. Jumlah penduduk miskin adalah banyaknya penduduk yang tidak mampu memenuhi standar hidup minimum mereka yang dinyatakan dalam satuan Jiwa

\section{Teknik Analisis Data}

Teknik analisis data yang digunakan dalam penelitian ini adalah menggunakan Model Regresi Linear Berganda (Multiple Regression Analysis Model). Analisis regresi linear berganda bertujuan untuk menguji hipotesis tentang kekuatan variabel independen terhadap variabel dependen dengan Model sebagai berikut :

$$
\begin{array}{ll}
\mathrm{Y}=\alpha+\beta 1 \mathrm{X} 1+\beta 2 \mathrm{X} 2+\beta 3 \mathrm{X} 3+\mu \\
\text { Dimana : } & \\
\mathrm{Y} & \text { : Jumlah Penduduk Miskin (dalam jiwa) } \\
\alpha & : \text { Intercept } \\
\beta 1 \beta 2 \beta 3 & : \text { Koefisien regresi } \\
\mathrm{X} 1 & \text { : Pertumbuhan Ekonomi (dalam persen) } \\
\mathrm{X} 2 & \text { : Pendapatan Perkapita (dalam rupiah) } \\
\mathrm{X} 3 & \text { : Inflasi (dalam persen) } \\
\mathrm{X} 4 & \text { : Pengangguran (dalam persen) } \\
\mu & : \text { Term of Error }
\end{array}
$$

\section{HASIL PENELITIAN DAN PEMBAHASAN}

Regresi linear Pertumbuhan Ekonomi, Pendapatan Perkapita, Inflasi dan Pengangguran terhadap Jumlah Penduduk Miskin Sumatera Utara

Untuk mendapatkan hasil regresi antara variabel independent (pertumbuhan ekonomi, pendapatan perkapita, inflasi dan pengangguran) dan variabel dependen (jumlah penduduk miskin) maka digunakan data sekunder yang berasal dari BPS yang dicatat mulai dari tahun 2003-2014 dan diolah dengan menggunakan bantuan program komputer.Berikut ini hasil pengolahan data dengan menggunakan metode OLS (Ordinary Least Square). 
Tabel 1

Hasil Regresi

Coefficients $^{\mathbf{a}}$

\begin{tabular}{|c|c|c|c|c|c|c|}
\hline \multirow{2}{*}{\multicolumn{2}{|c|}{ Model }} & \multicolumn{2}{|c|}{$\begin{array}{c}\text { Unstandardized } \\
\text { Coefficients }\end{array}$} & \multirow{2}{*}{$\begin{array}{c}\begin{array}{c}\text { Standardized } \\
\text { Coefficients }\end{array} \\
\text { Beta }\end{array}$} & \multirow[b]{2}{*}{$\mathrm{t}$} & \multirow[b]{2}{*}{ Sig. } \\
\hline & & B & Std. Error & & & \\
\hline & (Constant) & 1573.496 & 509.806 & & 3.086 & .018 \\
\hline & $\mathrm{X} 1$ & -59.397 & 70.538 & -.177 & -.842 & .428 \\
\hline & $\mathrm{X} 2$ & -.008 & .007 & -.311 & -1.207 & .266 \\
\hline & X3 & 3.019 & 9.462 & .072 & .319 & .759 \\
\hline & $\mathrm{X} 4$ & 54.318 & 23.949 & .602 & 2.268 & .058 \\
\hline
\end{tabular}

a. Dependent Variable: Y

Dari hasil regresi diatas, dapat dibentuk model hasil estimasi sebagai berikut :

$Y=1572,496-59,397 X 1-0,008 X 2+3,019$ X3 + 54,318 X4

\section{Interpretasi Model}

Berdasarkan model estimasi diatas dapat dijelaskan pengaruh variabel independent yaitu nilai pertumbuhan ekonomi (X1), pendapatan perkapita (X2), inflasi (X3) dan pengangguran (X4) terhadap jumlah penduduk miskin Sumatera Utara sebagai berikut :

\section{Pertumbuhan Ekonomi}

Pertumbuhan Ekonomi ternyata berpengaruh negatif terhadap jumlah penduduk miskin di Sumatera Utara.Hal ini ditunjukkan oleh koefisien regresi X1, yaitu sebesar 59,397. Artinya, setiap kenaikan $1 \%$ pertumbuhan ekonomi, maka jumlah penduduk miskin akan turun sebesar 59,397\% (ceteris paribus).

\section{Pendapatan Perkapita}

Pendapatan Perkapita ternyata berpengaruh negatif terhadap jumlah penduduk miskin di Sumatera Utara.Hal ini ditunjukkan dengan nilai koefisien regresi X2, yaitu sebesar 0,008. Artinya, setiap kenaikan $1 \%$ pendapatan perkapita maka jumlah penduduk miskin akan turun sebesar $0,008 \%$ (ceteris paribus).

\section{Inflasi}

Inflasi ternyata berpengaruh positif terhadap Jumlah Penduduk Miskin di Sumatera Utara.Hal ini ditunjukkan dengan nilai koefisien regresi X3 yaitu sebesar 3,019. Artinya, setiap kenaikan $1 \%$ inflasi maka jumlah penduduk miskin akan naik 3,019\% (ceteris paribus). 


\section{Pengangguran}

Pengangguran ternyata berpengaruh positif terhadap Jumlah Penduduk Miskin di Sumatera Utara.Hal ini ditunjukkan dengan nilai koefisien regresi X4 yaitu sebesar 54,318. Artinya, setiap kenaikan $1 \%$ jumlah pengangguran maka jumlah penduduk miskin akan naik sebesar $54,318 \%$ (ceteris paribus).

\section{Pengujian Koefisien Regresi Secara Individual (Uji t Statistik) \\ 1. Pertumbuhan Ekonomi}

Untuk variabel pertumbuhan ekonomi diperoleh nilai t-hitung sebesar $-0,842$ dengan nilai probabilitas (signifikansi) sebesar 0,428. Dengan demikian Ho diterima, karena nilai probabilitas lebih besar dari nilai $\alpha$ $0,05(0,428>0,05)$ dan t-hitung $>$ t-tabel $(-0,842>-2,365)$. Berarti dapat disimpulkan bahwa variabel pertumbuhan ekonomi tidak berpengaruh nyata (signifikan) terhadap variabel jumlah penduduk miskin di Sumatera Utara dengan pengujian pada tingkat kepercayaan $95 \%$ ( $\alpha=5 \%)$.

\section{Pendapatan Perkapita}

Untuk variabel pendapatan perkapita diperoleh nilai t-hitung sebesar 1,207 dengan nilai probabilitas (signifikansi) sebesar 0,226. Dengan demikian Ho diterima, karena nilai probabilitas lebih besar dari nilai $\alpha$ $0,05(0,226>0,05)$ dan t-hitung $<$ t-tabel $(-1,207<2,365)$. Berarti dapat disimpulkan bahwa variabel pendapatan perkapita tidak berpengaruh nyata (signifikan) terhadap variabel jumlah penduduk miskin di Sumatera Utara dengan pengujian pada tingkat kepercayaan $95 \%(\alpha=5 \%)$.

\section{Inflasi}

Untuk variabel inflasi diperoleh nilai t-hitung sebesar 0,319 dengan nilai probabilitas (signifikansi) sebesar 0,759. Dengan demikian Ho diterima, karena nilai probabilitas lebih besar dari nilai $\alpha 0,05(0,759>$ $0,05)$ dan t-hitung $<$ t-tabel $(0,319<2,365)$. Berarti dapat disimpulkan bahwa variabel inflasi tidak berpengaruh nyata (signifikan) terhadap variabel jumlah penduduk miskin di Sumatera Utara dengan pengujian pada tingkat kepercayaan $95 \%(\alpha=5 \%)$.

\section{Pengangguran}

Untuk variabel pengangguran diperoleh nilai t-hitung sebesar 2,268 dengan nilai probabilitas (signifikansi) sebesar 0,058. Dengan demikian Ho diterima, karena nilai probabilitas lebih besar dari nilai $\alpha 0,05(0,058>$ 
$0,05)$ dan t-hitung $<$ t-tabel $(2,268<2,365)$. Berarti dapat disimpulkan bahwa variabel pengangguran tidak berpengaruh nyata (signifikan) terhadap variabel jumlah penduduk miskin di Sumatera Utara dengan pengujian pada tingkat kepercayaan $95 \%(\alpha=5 \%)$.

\section{Pengujian Koefisien Regresi Secara Bersamaan (Uji F Statistik)}

Untuk membuktikan nilai R-square tersebut diatas maka dilakukan pengujian dengan menggunakan uji $\mathrm{F}$.

Hipotesisnya adalah sebagai berikut :

$\mathrm{H}_{0}: \beta 1=\beta 2=0$

Ha $: \beta 1 \neq \beta 2 \neq 0$

Artinya, berdasarkan data yang tersedia, akan dilakukan pengujian terhadap $\beta 1$ dan $\beta 2$ secara bersama-sama, apakah sama dengan nol, yang berarti tidak berpengaruh signifikan terhadap variabel terikat, atau tidak sama dengan nol, yang berarti mempunyai pengaruh signifikan terhadap variabel terikat.

Tabel 2

Uji Anova

ANOVA $^{\mathrm{a}}$

\begin{tabular}{|ll|c|r|c|c|c|}
\hline \multicolumn{2}{|l|}{ Model } & $\begin{array}{c}\text { Sum of } \\
\text { Squares }\end{array}$ & Df & $\begin{array}{c}\text { Mean } \\
\text { Square }\end{array}$ & F & Sig. \\
\hline 1 & Regression & 374429.749 & 4 & 93607.437 & 4.050 & $.052^{\mathrm{b}}$ \\
& Residual & 161783.274 & 7 & 23111.896 & & \\
& Total & 536213.023 & 11 & & & \\
\hline
\end{tabular}

a. Dependent Variable: Y

b. Predictors: (Constant), X4, X1, X3, X2

Berdasarkan hasil output program spss, diperoleh nilai F-hitung sebesar 4,050 dengan nilai probabilitas (signifikansi) adalah sebesar 0,52. Dengan demikian Ho diterima, karena nilai F-hitung < F-tabel $(4,050<$ 4,120 ) dan nilai probabilitas (signifikansi) lebih besar dari nilai $\alpha 0,05$ $(0,052>0,05)$. Berarti dapat disimpulkan bahwa variabel X1 (pertumbuhan ekonomi), variabel X2 (pendapatan perkapita), variabel X3 (inflasi), dan variabel pengangguran tidak berpengaruh secara nyata (signifikan) terhadap jumlah penduduk miskin Sumatera Utara (Y) pada tingkat kepercayaan $95 \%(\alpha=5 \%)$. 


\section{Koefisien Determinasi $\left(\mathbf{R}^{2}\right)$}

Tabel 3

KOEFISIEN DETERMINASI

Model Summary

\begin{tabular}{|l|c|r|r|r|}
\hline Model & R & R Square & $\begin{array}{c}\text { Adjusted R } \\
\text { Square }\end{array}$ & $\begin{array}{c}\text { Std. Error of } \\
\text { the Estimate }\end{array}$ \\
\hline 1 & $.836^{\mathrm{a}}$ & .698 & .526 & 152.02597 \\
\hline
\end{tabular}

a. Predictors: (Constant), X4, X1, X3, X2

Berdasarkan hasil output program spss, dapat dilihat nilai R-square adalah sebesar 0,698 yang berarti bahwa variabel X1 (pertumbuhan ekonomi), X2 (pendapatan perkapita), X3 (inflasi), X4 (pengangguran) secara bersama-sama mampu memberikan penjelasan variasi jumlah penduduk miskin Sumatera Utara sebesar 69,8 \% sedangkan sisanya 30,2 $\%$ dijelaskan oleh variabel baru yang tidak disertakan dalam estimasi model.

\section{KESIMPULAN DAN SARAN}

\section{Kesimpulan}

Berdasarkan hasil penelitian mengenai pengaruh pertumbuhan ekonomi, pendapatan perkapita, inflasi dan pengangguran terhadap jumlah penduduk miskin di Sumatera Utara, maka dapat diambil kesimpulan sebagai berikut

1. Dari hasil uji F, disimpulkan bahwa pertumbuhan ekonomi, pendapatan perkapita, inflasi dan pengangguran selama periode 2003 sampai dengan 2014 tidak berpengaruh signifikan secara simultan terhadap jumlah penduduk miskin di Sumatera Utara pada tingkat signifikansi 5\%. Dengan demikian hipotesis penelitian ditolak.

2. Berdasarkan uji parsial (uji t), variabel pertumbuhan ekonomi, pendapatan perkapita, inflasi dan pengangguran tidak berpengaruh nyata terhadap variabel jumlah penduduk miskin di Sumatera Utara dengan pengujian pada tingkat kepercayaan $95 \%(\alpha=5 \%)$.

3. Nilai koefisien determinasi (R) sebesar 0,698 yang berarti bahwa variabel X1 (pertumbuhan ekonomi), X2 (pendapatan perkapita), X3 (inflasi) dan X4 (pengangguran) secara bersama-sama mampu memberikan penjelasan variasi jumlah penduduk miskin di Sumatera Utara sebesar 69.8 $\%$ sedangkan sisanya 30,2 \% dijelaskan oleh variabel baru yang tidak disertakan dalam estimasi model. 


\section{Saran}

Berdasarkan kesimpulan diatas, maka adapun beberapa saran dari penulis yaitu:

1. Pemerintah harus membuat sebuah kebijakan dan mengambil perananan yang cukup besar untuk dapat mendorong pencapaian pertumbuhan ekonomi yang lebih maju dengan menaikkan kapasitas produksi masyarakat agar mengurangi jumlah penduduk miskin di Provinsi Sumatera Utara.

2. Pemerintah harus membuka lapangan pekerjaan guna menyerap jumlah tenaga kerja yang dapat membantu masyarakat dalam memenuhi kebutuhan hidup mereka.

3. Dalam upaya mengurangi jumlah kemiskinan di Sumatera Utara, pemerintah dapat melakukan upaya dengan cara peningkatan sumber daya manusia, sumber daya alam dan meningkatkan teknologi. Semakin tinggi kualitas sumber daya manusia maka akan mengurangi jumlah penduduk miskin dan pemerintah dapat melakukan upaya seperti peningkatan fasilitas pendidikan, fasilitas kesehatan dan mengupayakan stabilitas harga, dimana ketiga aspek tersebut merupakan komponen penting dalam mengurangi jumlah penduduk miskin Provinsi Sumatera Utara.

\section{DAFTAR PUSTAKA}

Kuncoro, Mudrajad, 2004, Otonomi Dan Pembangunan Daerah: Reformasi, Perencanaan, Strategi, dan Peluang, Penerbit Erlangga, Jakarta.

Lincolin Arsyad. 1999. Ekonomi Pembangunan. Edisi Keempat. Yogyakarta: Penerbit BP STIE YKPN.

Nopirin. 2000. Ekonomi Moneter. Buku II. Edisi Kesatu. Cetakan Kesepuluh. BPFE UGM. Yogyakarta.

Pohan, Aulia, 2008. Kerangka Kebijakan Moneter dan Implikasinya di Indonesia.RajaGrafindo Persada, Jakarta.

Sukirno, Sadono. 2004, Makroekonomi Teori Pengantar, Edisi Ketiga.Penerbit Raja Grafindo Persada, Jakarta.

Sukirno, Sadono. 2000. Makro Ekonomi Modern. Jakarta: PT. Raja Grafindo Persada.

Samuelson, PA, dan Nordhaus WD. (2004). Ilmu Makroekonomi. Edisi Tujuh Belas, Diterjemahkan oleh Gretta, Theresa Tanoto, Bosco Carvallo, dan Anna Elly, PT.Media Global Edukasi, Jakarta.

Soegijoko dan Kusbiantoro. 1997. Bunga Rampai Perencanaan Pembangunan di Indonesia, Grasindo, Jakarta. 
Sumodiningrat, Gunawan, 1998. Membangun Perekonomian Rakyat, Pustaka Pelajar, Yogyakarta.

Tarigan, Robinson. 2005. Ekonomi Regional Teori dan Aplikasi Edisi Revisi. Jakarta: PT BumiAksara.64

Todaro, Michael P. 2003. Pembangunan Ekonomi Di Dunia Ketiga. Alih Bahasa: Aminuddin dan Drs.Mursid. Jakarta: Ghalia Indonesia. 